Research article

\title{
Tomato susceptibility to Fusarium crown and root rot: Effect of grafting combination and proteomic analysis of tolerance expression in the rootstock
}

\author{
Alessandro Vitale ${ }^{\text {a }}$, Mariapina Rocco ${ }^{\text {b }}$, Simona Arena ${ }^{c}$, Francesco Giuffrida ${ }^{\mathrm{d}}$, \\ Carla Cassaniti ${ }^{\mathrm{d}}$, Andrea Scaloni ${ }^{\mathrm{c}}$, Tonia Lomaglio ${ }^{\mathrm{e}}$, Vladimiro Guarnaccia ${ }^{\mathrm{a}}$, \\ Giancarlo Polizzi ${ }^{a}$, Mauro Marra ${ }^{\mathrm{f}, *}$, Cherubino Leonardi ${ }^{\mathrm{d}}$ \\ a Department of Agri-food and Environmental Systems Management, University of Catania, Catania 95123, Italy \\ ${ }^{\mathrm{b}}$ Department of Science and Technology, University of Sannio, Benevento 82100, Italy \\ c Proteomics \& Mass Spectrometry Laboratory, National Research Council, Naples 80147, Italy \\ d Department of Agricultural and Food Science, University of Catania, Catania 95123, Italy \\ e Department of Biosciences and Territory, University of Molise, Pesche, IS 86170, Italy \\ f Department of Biology, University of Rome "Tor Vergata", Rome 00133, Italy
}

\section{A R T I C L E I N F O}

\section{Article history:}

Received 6 June 2014

Accepted 8 August 2014

Available online 19 August 2014

\section{Keywords:}

Disease management

Fusarium oxysporum f. sp. radicis-lycopersici Grafting

Plant growth

Proteomics

\begin{abstract}
A B S T R A C T
Grafting can enhance the tolerance of vegetable crops to soilborne diseases. The aim of this study was to investigate whether different tomato scion-rootstock combinations may affect the plant susceptibility to Fusarium oxysporum f. sp. radicis-lycopersici (FORL), the causal agent of crown and root rot. A proteomic approach was used to investigate whenever the protein repertoire of the rootstock can be modified by FORL infection, in relation to cultivar susceptibility/tolerance to the disease. To this purpose, plants of tomato hybrids with different vigor, "Costoluto Genovese" (less vigorous) and "Kadima" (more vigorous), were grafted onto "Cuore di Bue" and "Natalia" hybrids, sensitive and tolerant versus FORL infections, respectively. Disease symptoms, plant biomasses, and protein expression patterns were evaluated 45 days after FORL inoculation. The extent of vascular discoloration caused by FORL in tomato plants grafted on "Natalia" rootstock $(0.12-0.37 \mathrm{~cm})$ was significantly lower than that of plants grafted on sensitive "Cuore di Bue" (1.75-6.50 cm). FORL symptoms significantly differed between "Costoluto Genovese" and "Kadima" scions only when grafted on sensitive rootstock. Shoot FW of non-inoculated "Kadima”/“Cuore di Bue" combination was 35\% lower than "Kadima"|"Natalia", whereas no difference was manifested in inoculated plants. Shoot FW of inoculated "Costoluto Genovese"|"Cuore di Bue" combination was decreased of $39 \%$, whereas that of "Costoluto Genovese"|“Natalia" of $11 \%$, compared to control plants. Proteomic results showed a higher representation of proteins associated with pathogen infection in the tolerant rootstock, compared to the sensitive one, meaning a direct involvement of plant defence mechanisms in the tomato response to the pathogen challenge.
\end{abstract}

๑) 2014 Elsevier Masson SAS. All rights reserved.
Abbreviations: FORL, Fusarium oxysporum f. sp. radicis-lycopersici; HR, hypersensitive response; FCRR, Fusarium crown and root rot; DI, disease incidence; SS, severity symptoms; IEF, isoelectric focusing; 2-DE, two-dimensional electrophoresis; MALDI-TOF MS, matrix assisted laser desorption ionization-time of flight mass spectrometry; PMF, peptide mass fingerprinting; nanoLC-ESI-LIT-MS/MS, nano-liquid chromatography-electrospray-linear ion trap-tandem mass spectrometry; PR, pathogenesis-related; SNK, Student-Newman-Keuls.

* Corresponding author. Department of Biology, University of Rome "Tor Vergata", Via della Ricerca Scientifica, 00133 Rome, Italy. Tel.: +39 0672594349; fax: +39062023500

E-mail addresses: marra1357@gmail.com, marra@uniroma2.it (M. Marra).

\section{Introduction}

Tomato (Solanum lycopersicum L.) is one of the most important crop species worldwide and particularly in the Mediterranean basin. Due to its economic importance, as well as many favorable genetic and agricultural features, it has also become a model species for molecular studies aimed at improving fruit quality (Giovannoni, 2004; Rocco et al., 2006) and resistance toward pathogens (Ercolano et al., 2012). Tomato is affected by over 200 diseases induced by viruses, bacteria, fungi or nematodes (Jones et al., 1991), which are the cause of severe annual yield losses worldwide. 
In order to protect themselves from pathogens, plants have evolved a widely diffused non-specific mechanism named basal defence, which confers a broad-spectrum resistance and is based on the recognition of elicitor molecules from pathogens or pathogenassociated molecular patterns (PAMPs) (Boller and Felix, 2009). In addition to that, some plant varieties also present a specific mechanism toward the pathogen, also known as gene-for-gene resistance, which triggers in the infected plant a stronger defence response, referred to as hypersensitive response (HR) (Grant and Mansfield, 1999). Resistance mechanisms have been extensively studied in tomato and the interaction with the biotrophic fungus Passalora fulva (Cooke) U. Braun and Croushas, become a model pathosystem for gene-for-gene resistance studies (Thomma et al., 2005). Recently, functional approaches, including proteomics, have greatly contributed to the molecular dissection of plant-pathogen interactions, allowing to identify a number of defence-related candidate proteins and helping to clarify specific gene expression patterns (Metha et al., 2008). In tomato, proteomic studies have been performed to investigate response to bacteria (Afroz et al., 2009; Dahal et al., 2010; Savidor et al., 2012), virus (Casado-Vela et al., 2006) and fungi (Houtermann et al., 2007; Mazzeo et al., 2014).

Among tomato diseases, Fusarium crown and root rot (FCRR), caused by Fusarium oxysporum Schltdl.: Fr f. sp. radicis-lycopersici (FORL), is one of the most destructive diseases worldwide (Jones et al., 1991). This fungus, together with other emerging and wellestablished soilborne pathogens (Aiello et al., 2013; Dimartino et al., 2011; Vitale et al., 2011), represents a serious threat for tomato production in South Italy and, particularly, in South-eastern Sicily, where FCRR can cause yield losses up to $40 \%$. The current disinfestation measures to control FORL, such as chemicals or soil solarization, have various limitations related to poor efficacy, pathogen thermo-tolerance and high costs (Jones et al., 1991; Vitale et al., 2013). Accordingly, other sustainable measures are needed in controlling this disease.

Alternatively, one of the methods for FCRR control is represented by the use of tolerant scion-rootstock combinations. Grafting is a technique adopted to increase the yield and tolerance to several soilborne pathogens in vegetables since 1920 (Lee, 1994). Besides the advantages on pathogen control, this technique is worldwide diffused for many crops to improve yield (Bletsos, 2003; Cassaniti et al., 2011), fruit quality (Savvas et al., 2011) and tolerance to a variety of abiotic stresses (Rivero et al., 2003; Giuffrida et al., 2013). It has been reported that tomato grafted plants show higher yield than ungrafted ones (Martínez-Rodríguez et al., 2002), and that their growth is dependent upon the interaction between rootstock and scion (e.g. using intra- or inter-specific rootstocks) (Leonardi and Giuffrida, 2006). Although studies on the growth of grafted plants allowed to attribute enhanced fitness to different physiological aspects of plant response to abiotic stresses, such as water assimilation and ion uptake/translocation (Martínez-Ballesta et al., 2010), the molecular mechanisms for the improvement of yield, quality, as well as pathogen resistance of grafted plants are very poorly understood.

In this scenario, the aim of the present study was to assess whether the susceptibility to FORL of tomato plants may be affected by scion-rootstock combinations and to investigate whenever the tolerance to FORL can influence the representation of the protein repertoire in the rootstock.

\section{Materials and methods}

\subsection{Plant material and fungal infection}

Tomato seedlings of "Costoluto Genovese" (less vigorous) and "Kadima" (more vigorous) were grafted onto two rootstocks,
"Cuore di Bue" and "Natalia". The rootstocks were selected according to their different susceptibility/tolerance to FORL ("Cuore di Bu", sensitive; "Natalia", tolerant). The experiments were performed in the late autumn-winter 2009-2010 in a growth cabinet (3.4 m $\times 2.4 \mathrm{~m} \times 2.6 \mathrm{~m}$; Hitec, Mecter S.a.s., Catania, Italy) of DiGeSA (Dipartimento di Gestione dei Sistemi Agroalimentari e Ambientali).

An isolate of FORL (DiGeSA-Fot5) was selected for the inoculation trials. Fresh cultures of this isolate were obtained by transferring agar plugs from colonized stock cultures onto potato dextrose agar (PDA, Oxoid, UK) plates. Cultures were incubated at $25{ }^{\circ} \mathrm{C}$ for 7 days, in the dark, before use. Two 6-mm-diameter mycelial plugs from active growing margins of 7-day-old fungal colonies were inoculated at the same time, at the soil line near crown portion of 30 day-old tomato plants. Thirty-two tomato plants ( 4 replicates each formed by 8 plants) were used for each rootstock-scion combination. Only PDA mycelial plugs were placed in the same number of plants and served as controls. All treatments were arranged in a randomized complete block design. Plants were covered with plastic bags for $48 \mathrm{~h}$ and then maintained in the growth chamber at $25 \pm 1{ }^{\circ} \mathrm{C}$, with a regime of $16 \mathrm{~h}$ of light and $8 \mathrm{~h}$ of darkness at about $70 \%$ of relative humidity. Disease evaluation was performed 45 days after FORL inoculation. All seedlings were gently uprooted and the crowns and stems examined for symptoms of infection. Re-isolation of the pathogen was performed from two plants per replicate. Infected crown and stem tissue were surfacedisinfested for $2 \mathrm{~min}$ in $\mathrm{NaOCl}$ solution (1.5\%), rinsed in sterile water and plated on PDA plates. Developing fungal colonies were identified on the basis of morphological characteristics. To determine disease incidence (DI), all plants were sectioned to ascertain the presence of disease symptoms and the percentage of infected tomato plants. In addition, the length $(\mathrm{cm})$ of vascular discoloration along each tomato stem was measured as severity symptoms (SS). Shoot fresh weight, height and leaf number were also determined.

\subsection{Protein extraction}

Protein mining was performed according to the phenol extraction method (Rocco et al., 2006), with minor modifications. Briefly, rootstocks from non-inoculated control and infected "Kadima"/ "Cuore di Bue" and "Kadima”/“Natalia”combinations, were finely powdered in liquid $\mathrm{N}_{2}$ using a mortar and dried under vacuum. One gram of dried material was suspended in $20 \mathrm{ml}$ of ice-cold extraction buffer (700 mM sucrose, $500 \mathrm{mM}$ Tris- $\mathrm{HCl} \mathrm{pH} 7.5$, $50 \mathrm{mM}$ EDTA, $100 \mathrm{mM} \mathrm{KCl}, 2 \% \mathrm{w} / \mathrm{v} \beta$-mercaptoethanol, $1 \mathrm{mM}$ PMSF, $1 \% \mathrm{w} / \mathrm{v}$ PVP, $0.25 \% \mathrm{w} / \mathrm{v}$ CHAPS, $40 \mathrm{mM}$ NaF, $1 \mu \mathrm{M}$ okadaic acid). After addition of an equal volume of phenol saturated-500 mM Tris- $\mathrm{HCl}$, $\mathrm{pH} 7.5$, the mixture was stirred for $5 \mathrm{~min}$ in a Waring blender and then centrifuged at $10,000 \times g$ for $10 \mathrm{~min}$, at $4{ }^{\circ} \mathrm{C}$. The upper phenol phase was removed and extracted once again with the extraction buffer. Proteins were precipitated from the phenol phase by addition of 5 vol of saturated ammonium acetate in methanol, overnight at $-20^{\circ} \mathrm{C}$. Precipitated proteins were centrifuged at $10,000 \times \mathrm{g}$, for $30 \mathrm{~min}$, and stored at $-80^{\circ} \mathrm{C}$, until used. Three biological replicates were analyzed; all were subjected to independent phenol extraction and subsequent 2-D electrophoresis.

\subsection{2-D electrophoresis}

Protein pellets were dissolved in IEF buffer ( $9 \mathrm{M}$ urea, $4 \% \mathrm{w} / \mathrm{v}$ CHAPS, 0.5\% v/v Triton X-100, 20 mM DTT, 1\% w/v Bio-Rad carrier ampholytes $\mathrm{pH}$ 3-10). Protein concentration was estimated by using the Bradford assay, modified according to Ramagli and Rodriguez (1985). IPG strips (17 cm pH 3-10, Bio-Rad ReadyStrip, Bio-Rad) were rehydrated overnight with $300 \mu$ l of IEF buffer 
containing $300 \mu \mathrm{g}$ of total proteins. Proteins were focused using a Protean IEF Cell (Bio-Rad) at $12{ }^{\circ} \mathrm{C}$, by applying the following voltages: $250 \mathrm{~V}(90 \mathrm{~min}), 500 \mathrm{~V}(90 \mathrm{~min}), 1000 \mathrm{~V}(180 \mathrm{~min})$ and $8000 \mathrm{~V}$ for a total of $52 \mathrm{KVh}$ (Rocco et al., 2006). After focusing, the proteins were reduced by incubating the IPG strips with $1 \% \mathrm{w} / \mathrm{v}$ DTT in $10 \mathrm{ml}$ of equilibration buffer ( $50 \mathrm{mM}$ Tris- $\mathrm{HCl} \mathrm{pH} 8.8,6 \mathrm{M}$ urea, $30 \% \mathrm{w} / \mathrm{v}$ glycerol, $2 \% \mathrm{w} / \mathrm{v}$ SDS and a dash of bromophenol blue) for $15 \mathrm{~min}$, and then alkylated with $2.5 \% \mathrm{w} / \mathrm{v}$ iodoacetamide in $10 \mathrm{ml}$ of equilibration buffer, for $15 \mathrm{~min}$. Electrophoresis in the second dimension was carried out on $12 \%$ polyacrylamide gels $(180 \times 240 \times 1 \mathrm{~mm})$ with a Protean apparatus (Bio-Rad), using electrophoresis buffer ( $25 \mathrm{mM}$ Tris- $\mathrm{HCl}$ pH 8.3, $1.92 \mathrm{M}$ glycine and $1 \% \mathrm{w} / \mathrm{v}$ SDS), with $120 \mathrm{~V}$ applied for $12 \mathrm{~h}$, until the dye front reached the bottom of the gel. 2-DE gels were then stained with colloidal Coomassie G250; resulting images were acquired by using a GS-800 imaging systems (Bio-Rad). For quantitative analysis, each biological sample was analyzed in technical triplicate.

\subsection{Gel image analysis}

Digitized images of Coomassie-stained gels were analyzed by using the PD Quest (ver 7.4) 2-D analysis software (Bio-Rad), which allowed spot detection, landmarks identification, aligning/matching of spots within gels, quantification of matches spots and their analysis, according to manufacturer's instructions. Manual inspection of the spots was performed to verify the accuracy of automatic gel matching; any error in the automatic procedure was manually corrected prior to the final data analysis. The spot volume was used as the analysis parameter for quantifying protein expression. The protein spot volume was normalized to the spot volume of the entire gel (i.e., of all the protein spots). Fold-changes in protein spot levels were calculated between spot volumes in the treated group relative to that in the control gels. Statistically significant changes in protein expression were determined by using two sequential data analysis criteria. First, a protein spot had to be present in all gels for each sample to be included in the analysis. Next, statistically significant changes in protein expression were determined by using the distribution of fold-change values in the data. Spots were determined to be statistically significant (by Student's $t$ test) if the difference between the average intensity of a specific protein spot in the control and treated plants (three technical replicates of three biological samples) was greater than one standard deviation of the spot intensities for both groups. An absolute two-fold change in normalized spot densities was considered indicative of a differentially modified protein; values $\geq 2$ or $\leq 0.5$ were associated with increased or decreased protein amounts after treatment, respectively.

\subsection{Protein digestion and MS analysis}

Spots from 2-DE were manually excised from gels, triturated and washed with water. Proteins were in-gel reduced, S-alkylated and digested with trypsin, as previously reported (Talamo et al., 2003). Protein digests were subjected to a desalting/concentration step on microZipTipC18 pipette tips (Millipore Corp., Bedford, MA, USA) before MALDI-TOF-MS and/or nanoLC-ESI-LIT-MS/MS analysis.

During MALDI-TOF peptide mass fingerprinting (PMF) experiments, peptide mixtures were loaded on the instrument target together with $\alpha$-cyano-4-hydroxycinnamic acid as matrix, using the dried droplet technique. Samples were analyzed with a Bruker Ultraflextreme MALDI-TOF-TOF instrument (Bruker Daltonics). Peptide mass spectra were acquired in reflectron mode; external mass calibration was performed with Peptide Calibration Standard II (Bruker Daltonics) using the nearest neighbor positions. Data were elaborated using the FlexAnalysis software (Bruker Daltonics).
Peptide mixtures were also analyzed by nanoLC-ESI-LIT-MS/MS using a LTQ XL mass spectrometer (ThermoFinnigan, USA) equipped with Proxeon nanospray source connected to an Easy-nanoLC (Proxeon, Denmark) (Scippa et al., 2010). Peptide mixtures were separated on an Easy $\mathrm{C}_{18}$ column $(100 \times 0.075 \mathrm{~mm}, 3 \mu \mathrm{m})$ (Proxeon) using a gradient of acetonitrile containing $0.1 \%$ formic acid in aqueous $0.1 \%$ formic acid; acetonitrile ramped from $5 \%$ to $35 \%$ over $15 \mathrm{~min}$ and from $35 \%$ to $95 \%$ over $2 \mathrm{~min}$, at a flow rate of $300 \mathrm{nl} / \mathrm{min}$. Spectra were acquired in the range $m / z 400-2000$. Acquisition was controlled by a data-dependent product ion scanning procedure over the three most abundant ions, enabling dynamic exclusion (repeat count 2 and exclusion duration $1 \mathrm{~min}$ ). The mass isolation window and the collision energy were set to $\mathrm{m} / \mathrm{z} 3$ and $35 \%$, respectively.

\subsection{Protein identification}

MASCOT software package version 2.2.06 (Matrix Science, UK) was used to identify spots from an updated plant non-redundant sequence database (UniProt 2011/06). MALDI-TOF PMF data were searched using a mass tolerance value of $40-80 \mathrm{ppm}$, trypsin as proteolytic enzyme, a missed cleavages maximum value of 2 and Cys carbamidomethylation and Met oxidation as fixed and variable modification, respectively. NanoLC-ESI-LIT-MS/MS data were searched by using a mass tolerance value of 2 Da for precursor ion and 0.8 Da for MS/MS fragments, trypsin as proteolytic enzyme, a missed cleavages maximum value of 2 and Cys carbamidomethylation and Met oxidation as fixed and variable modification, respectively. MALDI-TOF PMF candidates with a cumulative MASCOT score $>83$, which were also confirmed by PSD data (data not shown), or nanoLC-ESI-LIT-MS/MS candidates with at least 2 assigned unique peptides with an individual MASCOT score $>25$, both corresponding to $p<0.05$ for a significant identification, were further evaluated by the comparison with their calculated $\mathrm{Mr}$ and $\mathrm{pI}$ values, using the experimental ones obtained from 2-DE.

\subsection{Statistical analysis}

All data obtained from the inoculation trials were subjected to analysis of variance according to parametric and non-parametric approaches (Statistica 10; StatSoft Inc.) with factorial treatment structure and interactions. All DI percentage data were transformed using arcsine $(\sin -1$ square $\operatorname{root} x)$ prior to statistical analysis. The untransformed values of DI (\%) are presented in Table 1 and separated by Fisher's least significant difference test $(P<0.05$ and 0.01$)$. SS data were analyzed according to a non-parametric approach, since the length of vascular discoloration of tomato had a nonnormal distribution. In detail, one-way analysis through the Man$\mathrm{n}$-Whitney test $(P<0.05)$ was used to evaluate the SS differences among scions, rootstocks and scion/rootstock combinations tested.

\section{Results}

\subsection{Disease symptoms and growth response}

Tomato seedlings of "Costoluto Genovese" (less vigorous) and "Kadima" (more vigorous) were grafted onto two rootstocks, namely "Cuore di Bue" and "Natalia", chosen according to their different sensitivity to FORL ("Cuore di Bue", sensitive; "Natalia", tolerant). After inoculation with FORL for 45 days, plants were collected and FCCR symptoms evaluated as disease incidence, (DI, \%, presence or absence of the pathogen) and severity symptoms, (SS, length of vascular browning) (Supplementary data, Fig. S1). Shoot fresh weight (FW), height and leaf number were also determined. As far as FCCR symptoms, significant interactions among tested factors 
Table 1

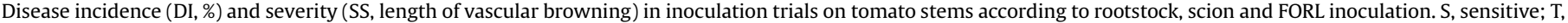
tolerant; $+\mathrm{V}$, more vigorous; $-\mathrm{V}$, less vigorous.

\begin{tabular}{|c|c|c|c|c|}
\hline Rootstock & Scion & Inoculation & $\mathrm{DI}(\%)^{\mathrm{c}}$ & $\mathrm{SS}(\mathrm{cm})^{\mathrm{c}}$ \\
\hline \multirow[t]{2}{*}{ Cuore di Bue $(S)^{\mathrm{a}}$} & Costoluto Genovese $(-\mathrm{V})$ & Control & $0.0 \mathrm{~b}$ & $0.0 \mathrm{~b}$ \\
\hline & & FORL & $100 \mathrm{a}$ & $6.50 \mathrm{a}$ \\
\hline \multirow[t]{2}{*}{ Cuore di Bue (S) } & Kadima $(+V)$ & Control & $0.0 \mathrm{~b}$ & $0.0 \mathrm{~b}$ \\
\hline & & FORL & $100 \mathrm{a}$ & $1.75 \mathrm{a}$ \\
\hline \multirow[t]{2}{*}{ Natalia $(\mathrm{T})$} & Costoluto Genovese $(-\mathrm{V})$ & Control & $0.0 \mathrm{a}$ & $0.0 \mathrm{a}$ \\
\hline & & FORL & $25.0 \mathrm{a}$ & $0.37 \mathrm{a}$ \\
\hline \multirow{2}{*}{ Natalia $(\mathrm{T})$} & Kadima $(+V)$ & Control & $0.0 \mathrm{a}$ & $0.0 \mathrm{a}$ \\
\hline & & FORL & $6.25 \mathrm{a}$ & $0.12 \mathrm{a}$ \\
\hline \multicolumn{5}{|l|}{ ANOVA } \\
\hline Rootstock (R) & & & & $* * *$ \\
\hline Scion $(S)$ & & & & $* * *$ \\
\hline Inoculation (In) & & & & $* * *$ \\
\hline $\mathrm{R} \times \mathrm{S} ; \mathrm{R} \times \mathrm{In} ; \mathrm{S} \times \mathrm{In} ; \mathrm{R} \times \mathrm{S} \times \mathrm{In}$ & & & & $* * *$ \\
\hline \multirow{2}{*}{$\begin{array}{l}\mathrm{K} \times \mathrm{S} \text {; } \mathrm{K} \times \mathrm{In} ; \mathrm{S} \times \mathrm{In} ; \mathrm{K} \times \mathrm{S} \times \mathrm{In} \\
\text { Cuore di Bue }(\mathrm{S})^{\mathrm{b}}\end{array}$} & Costoluto Genovese $(-\mathrm{V})$ & FORL & $100 \mathrm{a}$ & $6.50 \mathrm{a}$ \\
\hline & Kadima $(+\mathrm{V})$ & FORL & $100 \mathrm{a}$ & $1.75 \mathrm{~b}$ \\
\hline \multirow[t]{2}{*}{ Natalia $(\mathrm{T})$} & Costoluto Genovese $(-\mathrm{V})$ & FORL & $25.0 \mathrm{a}$ & $0.37 \mathrm{a}$ \\
\hline & Kadima $(+\mathrm{V})$ & FORL & $6.25 \mathrm{a}$ & $0.12 \mathrm{a}$ \\
\hline \multicolumn{5}{|l|}{ ANOVA } \\
\hline Rootstock (R) & & & & $* * *$ \\
\hline Scion $(S)$ & & & & $* * *$ \\
\hline $\mathrm{R} \times \mathrm{S}$ & & & & $* * *$ \\
\hline Cuore di Bue $(S)^{b}$ & & FORL & $100 \mathrm{a}$ & $4.12 \mathrm{a}$ \\
\hline Natalia $(\mathrm{T})$ & & FORL & $15.6 \mathrm{~b}$ & $0.25 \mathrm{~b}$ \\
\hline
\end{tabular}

a Significant differences between control and inoculated plants are reported for each rootstock/scion combination tested since there were significant interactions among

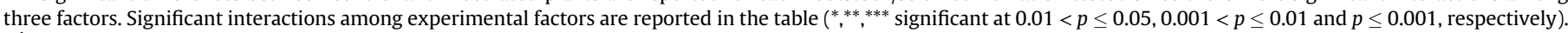

b Only inoculated plants were compared between two scions grafted onto each rootstock and between two rootstocks to evaluate their FORL susceptibility.

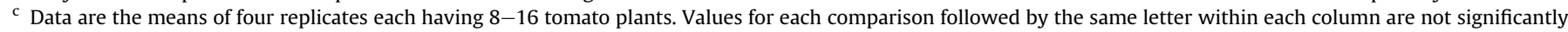

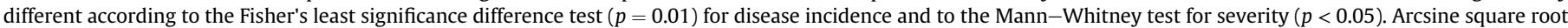
transformation was applied on percentage prior to data analysis.

(rootstock, scion and inoculation) were always observed; thus, the mean DI and SS were compared between control and inoculated tomato plants for each scion-rootstock combination (Table 1). DI and SS data detected in inoculated tomato plants were significantly higher than control ones in "Costoluto Genovese"|"Cuore di Bue" and "Kadima”|“Cuore di Bue" combinations, whereas both scions grafted onto tolerant "Natalia" rootstock were not significantly affected by FORL inoculation (Table 1). Therefore, "Natalia" rootstock conferred tolerance towards FORL infections, even when a less vigorous scion ("Costoluto Genovese") was used.

Table 2

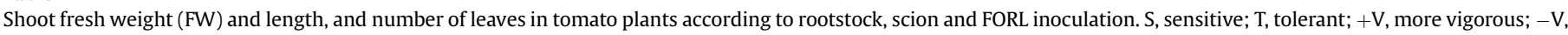
less vigorous.

\begin{tabular}{|c|c|c|c|c|c|}
\hline Rootstock & Scion & Inoculation & Shoot FW (gram plant ${ }^{-1}$ ) & Shoot length $(\mathrm{cm})$ & Leaves $(n)$ \\
\hline Cuore di Bue (S) & & & $14.1 \mathrm{~b}$ & 23.6 & 10.5 \\
\hline \multirow[t]{5}{*}{ Natalia $(\mathrm{T})$} & & & $17.1 \mathrm{a}$ & 26.0 & 11.0 \\
\hline & Kadima $(+\mathrm{V})$ & & $17.2 \mathrm{a}$ & 30.9 a & 10.9 \\
\hline & Costoluto Genovese $(-\mathrm{V})$ & & $13.9 \mathrm{~b}$ & $18.7 \mathrm{~b}$ & 10.6 \\
\hline & & Control & 16.1 & 24.8 & 10.7 \\
\hline & & FORL & 15.1 & 24.8 & 10.8 \\
\hline \multirow[t]{2}{*}{ Cuore di Bue (S) } & Kadima $(+\mathrm{V})$ & & 15.0 & 28.6 & $11.1 \mathrm{a}$ \\
\hline & Costoluto Genovese $(-\mathrm{V})$ & & 13.1 & 18.6 & $9.9 \mathrm{~b}$ \\
\hline \multirow[t]{2}{*}{ Natalia (T) } & Kadima $(+\mathrm{V})$ & & 19.5 & 33.3 & $10.8 \mathrm{a}$ \\
\hline & Costoluto Genovese $(-\mathrm{V})$ & & 14.8 & 18.8 & $11.2 \mathrm{a}$ \\
\hline \multirow[t]{2}{*}{ Cuore di Bue (S) } & & Control & 14.5 & 23.8 & 10.4 \\
\hline & & FORL & 13.6 & 23.4 & 10.6 \\
\hline \multirow[t]{6}{*}{ Natalia (T) } & & Control & 17.6 & 25.9 & 10.9 \\
\hline & & FORL & 16.6 & 26.1 & 11.0 \\
\hline & Kadima $(+\mathrm{V})$ & Control & 16.2 & 30.2 & 10.6 \\
\hline & & FORL & 18.3 & 31.6 & 11.3 \\
\hline & Costoluto Genovese $(-\mathrm{V})$ & Control & 15.9 & 19.5 & 10.8 \\
\hline & & FORL & 11.9 & 17.9 & 10.3 \\
\hline \multicolumn{6}{|l|}{ ANOVA } \\
\hline Rootstock (R) ${ }^{\mathrm{a}}$ & & & $* *$ & NS & NS \\
\hline Scion $(S)$ & & & $* *$ & $* * *$ & NS \\
\hline Inoculation (In) & & & NS & NS & NS \\
\hline $\mathrm{R} \times \mathrm{S}$ & & & NS & NS & $*$ \\
\hline $\mathrm{R} \times \mathrm{In}$ & & & NS & NS & NS \\
\hline $\mathrm{S} \times \operatorname{In}$ & & & $*$ & NS & NS \\
\hline $\mathrm{R} \times \mathrm{S} \times \mathrm{In}^{\mathrm{b}}$ & & & $*$ & NS & NS \\
\hline
\end{tabular}

${ }^{a} \mathrm{NS}=$ not significant; ${ }^{*}, * * * *$ significant at $0.01<p \leq 0.05,0.001<p \leq 0.01$ and $p \leq 0.001$, respectively. In each column, values followed by different letters differ significantly at $p=0.05$ (SNK test).

$\mathrm{b}$ Data of significant interaction between experimental factors $(\mathrm{R} \times \mathrm{S} \times \mathrm{In})$ are reported in the figure. 


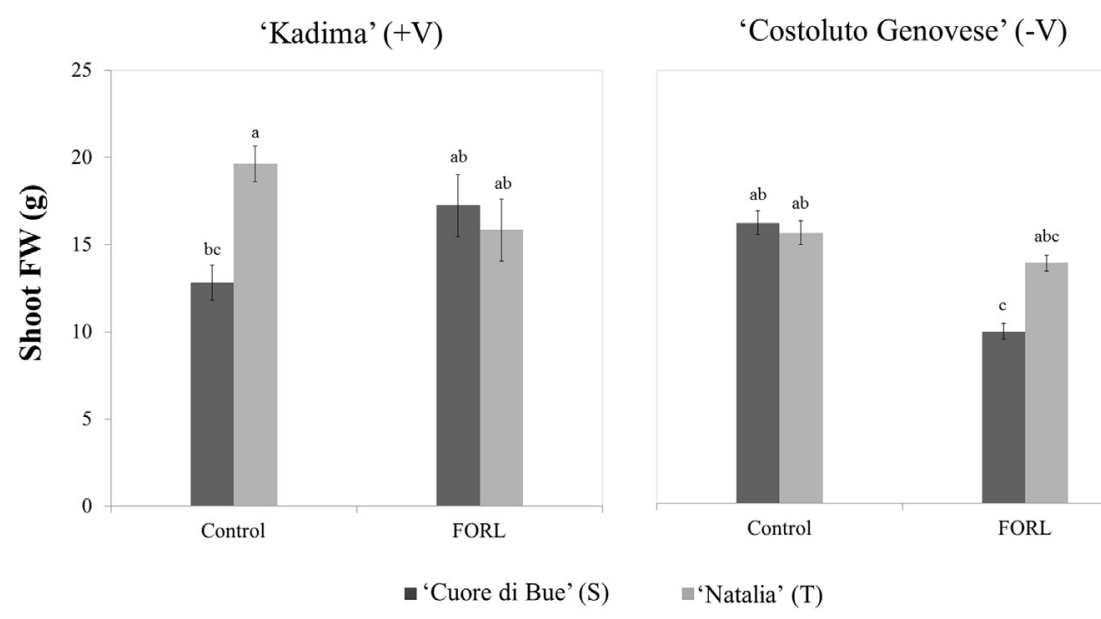

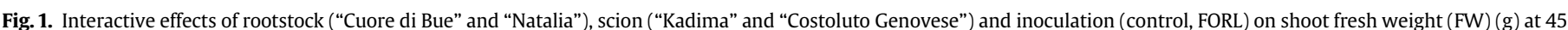

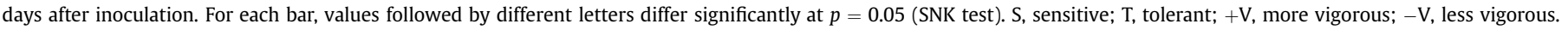

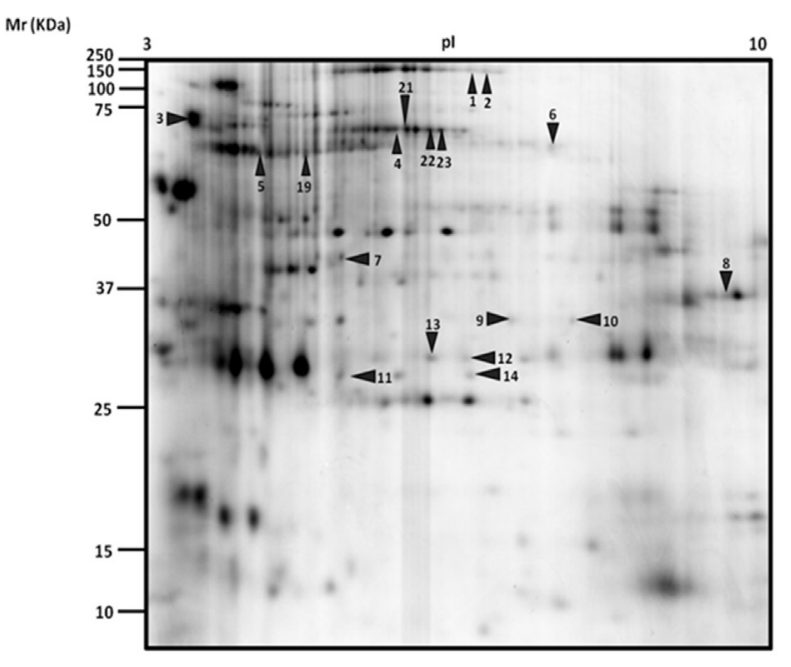

$\operatorname{Mr}(\mathrm{KDa})$

$\operatorname{Mr}(\mathrm{KDa})$

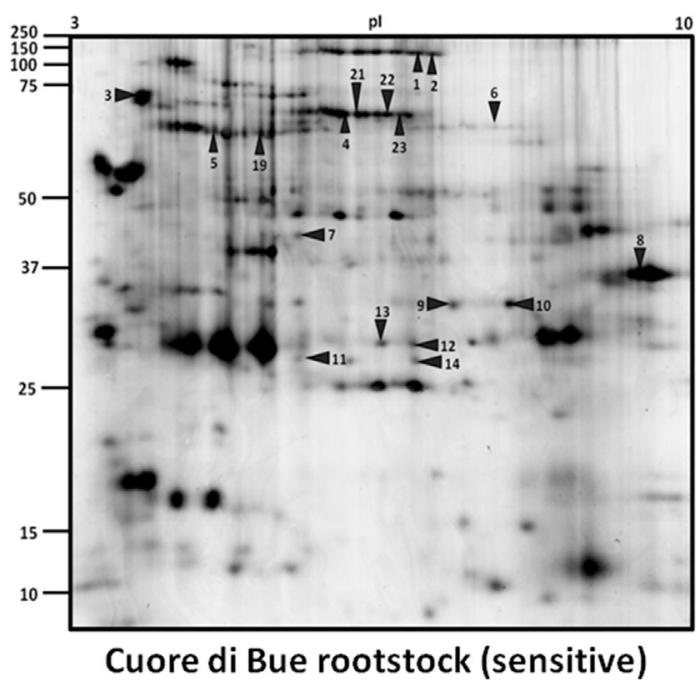

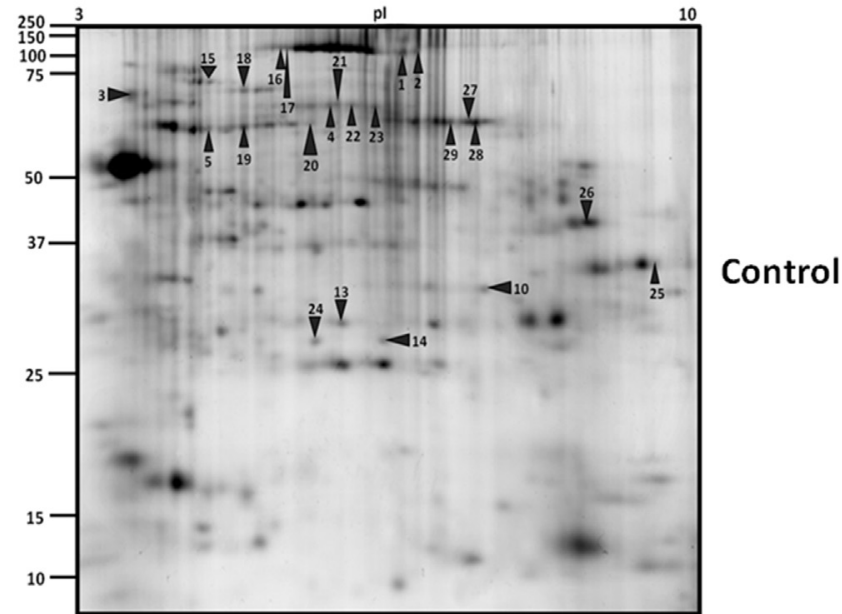

Mr (KDa)

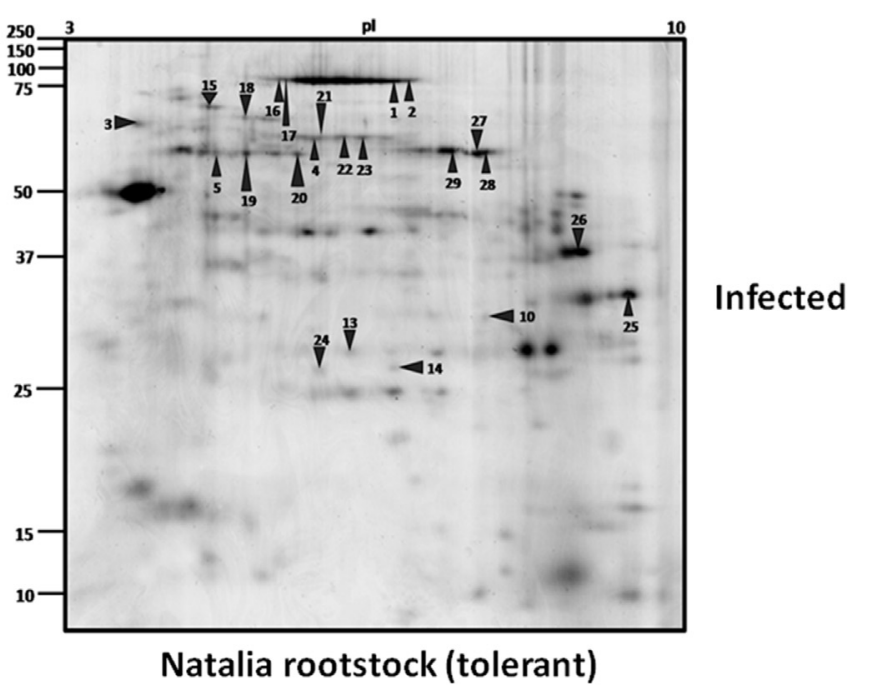

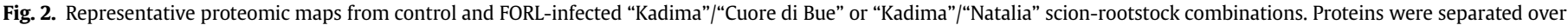

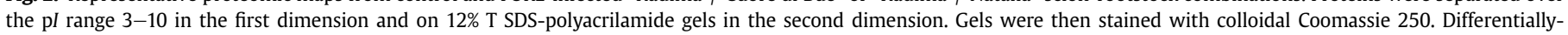
represented proteins are indicated; spot numbering is identical to that reported in Table 2. 
In addition, analyzing only susceptibility to FORL (inoculated tomato plants), it has been observed that "Kadima" showed a significantly lower SS to FORL infections than "Costoluto Genovese" only when plants were grafted onto "Cuore di Bue" (sensitive) and not onto the tolerant "Natalia" hybrid (Table 1). These data demonstrate the use of vigorous scion "Kadima" may reduce FORL infections even if a sensitive rootstock is used. As expected, FORL tolerance was statistically different, being "Cuore di Bue" significantly more susceptible to disease than "Natalia" (Table 1).

Also growth response significantly differed in accord with rootstock, scion and FORL inoculation (Table 2). When "Kadima" was used as scion, shoot FW of control plants grafted onto the sensitive "Cuore di Bue" was about 35\% lower than plants grafted onto the tolerant "Natalia" ( $p<0.005)$, whereas no difference was manifested between the two rootstocks in inoculated plants (Fig. 1). Shoot FW of inoculated plants with "Costoluto Genovese" scion decreased of about $39 \%$ compared to the non-inoculated control in plants grafted onto "Cuore di Bue", whereas a lowest reduction (about 11\%) was obtained for inoculated plants grafted onto the tolerant "Natalia", compared with the control $(p<0.005)$. In this case, the use of tolerant rootstock reduced significantly FORL infections, as it has been previously reported by other authors (Gilardi et al., 2011). For shoot length, only the scion led to significant differences: plants of "Kadima" were about 39\% taller than plants of "Costoluto Genovese" scion (Table 2). No significant differences occurred for leaf number when plants were grafted onto "Natalia" (Table 2). On the contrary, the use of "Cuore di Bue" as rootstock resulted in a higher number of leaves with "Kadima" than "Costoluto Genovese" scion (+11\%), confirming its major vigor.

\subsection{Proteomic analysis of rootstock proteins}

In order to evaluate the effect of the pathogen challenge onto the protein repertoire of tolerant versus sensitive rootstock, a comparative proteomic analysis of control and FORL-infected "Kadima"/“Cuore di Bue" (more vigorous/sensitive) and "Kadima"/"Natalia" (more vigorous/tolerant) scion-rootstock combinations was carried out. Total proteins were extracted from roots and stems until grafting union of "Cuore di Bue" and "Natalia" rootstocks 45 days after FORL inoculation, or from the

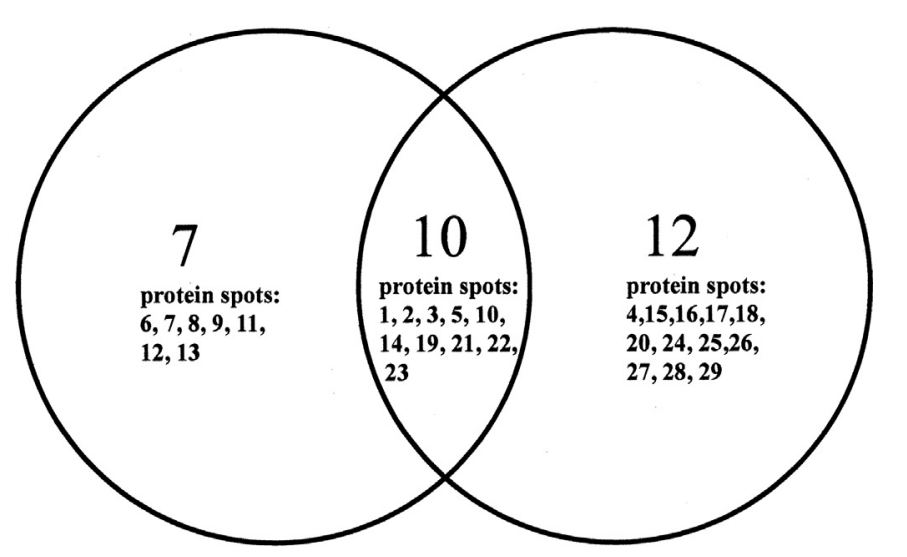

\section{Kadima/Cuore di Bue (sensitive rootstock)}

\section{Kadima/Natalia (tolerant rootstock)}

Fig. 3. Venn diagram of results from comparative proteomic analysis of inoculated $v s$ non-inoculated "Kadima"|“Cuore di Bue" and "Kadima”|“Natalia” scion-rootstock combinations. Reported proteins are those differentially-represented in each combination after 45 days of FORL infection, as evaluated with respect to the corresponding controls. Protein spots refer to identified proteins reported in Table 3. corresponding non-inoculated plants; corresponding protein extracts were then resolved by 2-D electrophoresis. Representative 2$\mathrm{D}$ gels are shown in Fig. 2. To ascertain quantitative changes in relative spot volumes for challenged plants compared to controls, colloidal Coomassie-stained gels were subjected to comparative software-assisted image analysis. Average proteomic maps showed: i) $285 \pm 11$ spots (inoculated), $276 \pm 9$ spots (control), ("Kadima"|"Cuore di Bue" scion-rootstock combination); ii) $254 \pm 7$ spots (inoculated), $231 \pm 4$ spots (control) ("Kadima"/ "Natalia") scion-rootstock combination). Statistical evaluation of the relative spot volumes allowed to detect spots significantly varying $(p<0.05)$ in abundance in inoculated plants, as compared to the control ones. In total, 29 protein spots were detected, whose abundance changed in rootstocks in response to pathogen challenge. A Venn diagram representation of differentially-induced spots, qualitatively indicated that FORL infection induced a higher number of proteins in resistant rootstocks. At the same time, a partial overlapping of the molecular effectors eliciting the response to the pathogen was observed between the sensitive and tolerant rootstocks (Fig. 3). Among differentially-represented protein spots present in the proteomic maps, 7 were exclusively identified in the "Cuore di Bue" rootstock (sensitive), 12 were detected only in the "Kadima" rootstock (tolerant), whereas 10 protein spots occurred both in the susceptible and tolerant rootstocks.

Differential spots were then excised from the gels, trypsinolyzed and subjected to MS analysis for further protein identification assignment. Two positive identifications derived from MALDI-TOF PMF analysis, whereas the remaining 27 resulted from nanoLC-ESI-LIT-MS/MS. Globally, spots assayed were associated with 21 non-redundant protein entries. The list of identified protein species is reported in Table 3, together with their quantitative variations in response to FORL challenge. Analysis of spot 7 resulted in a double identification (annexin p35/fruktokinase-2, spot 7), whereas spots 2, 4, 12 and 23 demonstrated the concomitant migration of different isozymes. Some proteins were present in multiple spots whose structural differences were not further characterized; probably, they resulted from post-translational modifications (PTMs) or sequence-related isozymes. Functional categorization according to Gene Ontology annotation and literature data (data not shown), showed that differentially-represented proteins grouped into three main broad classes, including components involved in i) stress response: glucan endo- $1,3 \beta$ glucosidase B (EC 3.2.1.39), endochitinase 4 (EC 3.2.1.14), chloroplastic polyphenol oxidase (EC 1.10.3.1), catalase isoenzymes 1 and 2 (EC 1.11.1.6), $70 \mathrm{kDa}$ heat shock protein, multicystatin. ii) carbohydrate metabolism: cytosolic triosephosphate isomerase (EC 5.3.1.1), phosphoglycerate mutase (EC 5.4.2.1), enolase (EC 4.2.1.11), fruktokinase-2 (EC 2.7.1.4). iii) protein turnover: proteasome subunit $\alpha$ type -3 and 6 (EC 3.4.25.1), leucine aminopeptidase 2 (LAP2) (EC 3.4.11.1).

\section{Discussion}

The present study demonstrates that scion-rootstock combinations significantly influence tomato sensitivity to FORL, as assessed by comparative disease symptoms and plant growth response evaluation. In fact, the amount of disease symptoms was strongly affected by the tolerant rootstock "Natalia" even when a less vigorous scion was used. Otherwise, when the more vigorous scion "Kadima" was grafted onto the susceptible rootstock "Cuore di Bue" it contributed in reducing FCRR symptoms. Hence, these data clearly indicate that grafting onto tolerant rootstock can be used as effective control measure in managing FCRR of tomato. Accordingly, results from proteomic analysis highlighted the specific accumulation in the tolerant rootstock of proteins grouping 
Table 3

Proteins identified as differentially-represented in the tomato rootstock from the different plants reported in this study. Spot number, NCBI accession, Uniprot accession, protein name, sequence coverage, number of unique peptides identified, Mascot score, theoretical and experimental $\mathrm{Mr}$ values, theoretical and experimental $\mathrm{p} I$ values are listed, together with the corresponding fold changes in sensitive and tolerant scion/rootstock combinations after FORL infection, with respect to conesponding controls. PMF, peptide mass fingerprinting; TMS, tanden mass spectrometry.

\begin{tabular}{|c|c|c|c|c|c|c|c|c|c|c|c|c|}
\hline Spot & Gi code & SP code & Protein name & $\begin{array}{l}\text { Sequence } \\
\text { coverage (\%) }\end{array}$ & $\begin{array}{l}\text { Peptides } \\
\text { (number) }\end{array}$ & $\begin{array}{l}\text { Mascot } \\
\text { score }\end{array}$ & $\begin{array}{l}\text { Theor. } \mathrm{pl} / \mathrm{Mr} \\
(\mathrm{kDa})\end{array}$ & $\begin{array}{l}\text { Exp. pI/Mr } \\
\text { (kDa) }\end{array}$ & Organism & ID method & $\begin{array}{l}\text { Relative fold change } \\
\text { infected/control } \\
\text { (sensitive) }\end{array}$ & $\begin{array}{l}\text { Relative fold change } \\
\text { infected/control } \\
\text { (tolerant) }\end{array}$ \\
\hline 1 & 3452387 & 081693 & Cysteine protease inhibitor & 33.1 & 5 & 192 & $5.43 / 29.0$ & $6.49 / 71.0$ & Solanum lycopersicum & TMS & 2.3 & 2.0 \\
\hline \multirow[t]{2}{*}{2} & 3452387 & 081693 & Cysteine protease inhibitor & 33.5 & 5 & 217 & $5.43 / 29.0$ & $6.64 / 71.1$ & Solanum lycopersicum & TMS & 2.0 & 0.5 \\
\hline & 6671196 & Q9SE07 & Multicystatin & 32.0 & 3 & 124 & $6.22 / 17.9$ & & Solanum lycopersicum & TMS & & \\
\hline 3 & 242032147 & C5WRV5 & $\begin{array}{l}\text { Putative uncharacterized } \\
\text { protein Sb01g000380 }\end{array}$ & 6.7 & 3 & 112 & $5.20 / 60.9$ & $3.40 / 64.4$ & Sorghum bicolor & TMS & 2.1 & 0.1 \\
\hline \multirow[t]{2}{*}{4} & 1172578 & Q08304 & Polyphenol oxidase B & 4.7 & 3 & 142 & $6.04 / 58.1$ & $5.88 / 61.1$ & Solanum lycopersicum & TMS & 1 & 2.0 \\
\hline & 1346775 & Q08306 & Polyphenol oxidase D & 7.8 & 3 & 84 & $6.04 / 57.9$ & & Solanum lycopersicum & TMS & & \\
\hline 5 & 114421 & P17614 & ATP synthase subunit beta & 18.0 & 7 & 106 & $5.13 / 54.1$ & $4.35 / 54.9$ & Nicotiana plumbaginifolia & PMF & 3.0 & 0.1 \\
\hline 6 & 587568 & P55312 & Catalase isozyme 2 & 7.9 & 3 & 142 & $6.56 / 56.4$ & $7.82 / 56.3$ & Solanum tuberosum & TMS & 2.1 & 1 \\
\hline \multirow[t]{2}{*}{7} & 3378204 & 081535 & Annexin $\mathrm{p} 35$ & 17.1 & 5 & 205.9 & $5.84 / 36.2$ & $5.24 / 40.0$ & Solanum lycopersicum & TMS & 0.1 & 1 \\
\hline & 75221385 & Q42896 & Fructokinase-2 & 19.8 & 4 & 224 & $5.76 / 34.8$ & & Solanum lycopersicum & TMS & & \\
\hline 8 & 461979 & Q01413 & Glucan endo-1,3-beta-glucosidase B & 21.0 & 6 & 90 & $9.00 / 35.0$ & $9.64 / 34.6$ & Solanum lycopersicum & PMF & 2.5 & 1 \\
\hline 9 & 222849327 & B9HQY8 & Predicted protein & 9.2 & 2 & 177 & $7.49 / 25.8$ & $7.28 / 31.9$ & Populus trichocarpa & TMS & 4.9 & 1 \\
\hline 10 & 222849327 & B9HQY8 & Predicted protein & 9.2 & 2 & 182 & $7.49 / 25.8$ & $7.97 / 31.9$ & Populus trichocarpa & TMS & 6.0 & 0.5 \\
\hline 11 & 38112662 & Q6T379 & Triosephosphate isomerase & 11.0 & 2 & 100 & $5.73 / 27.0$ & $5.22 / 26.9$ & Solanum chacoense & TMS & 0.5 & 1 \\
\hline \multirow[t]{2}{*}{12} & 12229948 & Q9XG77 & Proteasome subunit alpha type- 6 & 7.3 & 2 & 111 & $5.91 / 27.3$ & $6.33 / 27.1$ & Nicotiana tabacum & TMS & 3.5 & i \\
\hline & 259443289 & Q93X34 & Proteasome subunit alpha type- 3 & 10.4 & 2 & 89 & $6.10 / 27.2$ & & Nicotiana tabacum & TMS & & \\
\hline 13 & 12229948 & Q9XG77 & Proteasome subunit alpha type- 6 & 31.7 & 5 & 218 & $5.91 / 27.3$ & $6.70 / 27.1$ & Nicotiana tabacum & TMS & 4.2 & 1 \\
\hline 14 & 38112662 & Q6T379 & Triosephosphate isomerase & 16.1 & 3 & 193 & $5.73 / 27.0$ & $6.80 / 25.9$ & Solanum chacoense & TMS & 2.5 & 0.5 \\
\hline 15 & 300265 & Q08276 & Heat shock $70 \mathrm{kDa}$ protein & 22.1 & 9 & 350 & $5.43 / 67.0$ & $4.55 / 70.0$ & Lycopersicon peruvianum & TMS & 1 & 3.0 \\
\hline 16 & 415591 & P37842 & Multicystatin & 13.4 & 10 & 734 & $5.62 / 86.8$ & $5.38 / 79.8$ & Solanum tuberosum & TMS & 1 & 2.0 \\
\hline 17 & 415591 & P37842 & Multicystatin & 16.3 & 12 & 776 & $5.62 / 86.8$ & $5.44 / 80.0$ & Solanum tuberosum & TMS & 1 & 3.1 \\
\hline 18 & 4582924 & Q9XE59 & Phosphoglycerate mutase & 3.9 & 2 & 130 & $5.42 / 61.3$ & $4.94 / 67.8$ & Solanum tuberosum & TMS & 1 & 2.0 \\
\hline 19 & 119354 & P26300 & Enolase & 29.1 & 7 & 414 & $5.68 / 47.8$ & $4.94 / 54.8$ & Solanum lycopersicon & TMS & 2.0 & 2.4 \\
\hline 20 & 2492530 & Q42876 & Leucine aminopeptidase 2 & 6.2 & 2 & 99 & $6.33 / 54.2$ & $5.56 / 55.6$ & Solanum lycopersicon & TMS & 1 & 3.7 \\
\hline 21 & 1172578 & Q08304 & Polyphenol oxidase B & 5.0 & 2 & 98 & $6.04 / 58.1$ & $6.04 / 61.0$ & Solanum lycopersicon & TMS & 2.0 & 4.2 \\
\hline 22 & 1172578 & Q08304 & Polyphenol oxidase B & 22.5 & 10 & 446 & $6.04 / 58.1$ & $6.44 / 61.2$ & Solanum lycopersicon & TMS & 0.5 & 3.5 \\
\hline \multirow[t]{2}{*}{23} & 22731 & Q08306 & Polyphenol oxidase D & 10.5 & 4 & 208 & $6.04 / 57.9$ & $6.72 / 61.7$ & Solanum lycopersicon & TMS & 2.0 & 4.7 \\
\hline & 1172578 & Q08304 & Polyphenol oxidase B & 7.4 & 3 & 117 & $6.04 / 58.1$ & & Solanum lycopersicon & TMS & & \\
\hline 24 & 77745458 & P48495 & Triosephosphate isomerase & 35.0 & 4 & 150 & $5.54 / 27.1$ & $5.92 / 25.9$ & Solanum tuberosum & TMS & 1 & 7.7 \\
\hline 25 & 170382 & Q01413 & Glucan endo-1,3-beta-glucosidase B & 25.8 & 8 & 563 & $9.00 / 35.0$ & $9.60 / 34.8$ & Solanum lycopersicon & TMS & 1 & 5.6 \\
\hline 26 & 467826 & P52406 & Endochitinase 4 & 4.6 & 3 & 85 & $8.58 / 32.3$ & $9.00 / 39.8$ & Solanum tuberosum & TMS & i & 9.2 \\
\hline 27 & 587568 & P55312 & Catalase isozyme 2 & 21.5 & 8 & 400 & $6.56 / 56.4$ & $7.49 / 56.2$ & Solanum tuberosum & TMS & i & 3.1 \\
\hline 28 & 170398 & P30264 & Catalase isozyme 1 & 24.4 & 12 & 702 & $6.56 / 56.5$ & $7.59 / 56.3$ & Solanum lycopersicon & TMS & 1 & 7.2 \\
\hline 29 & 587568 & P55312 & Catalase isozyme 2 & 8.1 & 3 & 187 & $6.56 / 56.4$ & $7.36 / 56.3$ & Solanum tuberosum & TMS & 1 & 8.0 \\
\hline
\end{tabular}


into three main broad classes, namely stress response, carbohydrate metabolism and protein turnover, which, on the overall, can account for expression of tolerance to FORL.

As far as proteins involved in stress response, components of the group of pathogenesis related (PR) proteins, namely glucan endo$1,3 \beta$ glucosidase B (EC 3.2.1.39; spots 8 and 25) (PR-2 class) and endochitinase 4 (EC 3.2.1.14; spot 26) (PR-4 class), were identified as FORL-induced species in susceptible ("Cuore di Bue") and tolerant ("Natalia") tomato rootstocks. Whereas levels of the PR-2 member were increased in both susceptible and tolerant rootstocks after FORL infection, although to a different extent ( 2.5 fold in "Cuore di Bue"; 5.6 fold in "Natalia"), those of the PR-4 one were highly increased (9.2 fold) only in the tolerant rootstock. PR proteins are elicited in many plant species by the attack of different pathogens; they can be grouped into 17 families and present antimicrobial activities (van Loon et al., 2006). In particular, PR-2 proteins function as $\beta-1,3$-glucanases, whereas PR-4 ones act as endochitinases; both contribute to limit pathogen progression by degrading $\beta$-glucan and chitin molecules that are present in the fungal cell wall (van Loon et al., 2006). In tomato, different proteomic studies indicated that levels of $\beta-1,3$-glucanases are increased upon infection by various pathogens, i.e. Ralstonia solanacearum (Smith) Yabuuchi et al. (Dahal et al., 2009), Tobacco mosaic virus (Casado-Vela et al., 2006), Clavibacter michiganensis subsp. michiganensis (Smith) Davis et al. (Savidor et al., 2012) or Fusarium oxysporum (Houtermann et al., 2007), thereby pointing to an involvement of PR-2 proteins in the expression of the resistance. On the other hand, data from a recent comparative proteomic investigation on FORL infection of roots in resistant and susceptible tomato lines, showed that $\beta$-1,3-glucanases and endochitinases were accumulated only in susceptible plants (Mazzeo et al., 2014), thus suggesting that PR-2 or PR-4 proteins in resistant lines are not essential to the defense response.

Multiple species (spots 4, 21, 22 and 23) having similar mass but different $\mathrm{pI}$ values (very likely reflecting the occurrence of PTMs) were associated with two chloroplastic isoforms of polyphenol oxidases (PPOs; EC 1.10.3.1). After FORL infection, their amounts increased to a much greater extent in the resistant rootstock than in the susceptible one. Polyphenol oxidases catalyze the $\mathrm{O}_{2}$-dependent oxidation of mono- and $o$-di-phenols to $o$-quinones, which are involved in browning reactions as a consequence of pathogen infection, wounding or senescence (Mayer, 2006). Their role in protection against biotic stresses has not yet been fully elucidated, but down-regulation or over-expression of PPOs in transgenic tomato plants correlated with a reduced (Phypiapong et al., 2004) or enhanced (Li and Steffens, 2002) resistance to Pseudomonas syringae pv. Tomato, (Okabe) Young Dye and Wilkie, respectively. It has also been proposed that they may be involved in the generation of reactive oxygen species (ROS) (Phypiapong et al., 2004). Oxidative burst, as result of ROS generation, is a common mechanism associated with the plant response to pathogens; it can be particularly intense in the hypersensitive response (HR), leading to programmed death of infected cells (Grant and Mansfield, 1999). High levels of ROS hence can severely affect the integrity of cellular structures. During response to pathogens, the redox homeostasis, which is essential for innate immunity expression, is usually maintained by various plant antioxidant systems. Catalases are among the most efficient ROS scavengers in plants; they belong to a multi-gene family that is regulated by developmental stimuli or different environmental stresses (Du et al., 2008). In the resistant rootstock, catalase isoforms (catalase isoenzymes 1 and 2; EC 1.11.1.6) occurred as multiple spots (spots 27, 28 and 29) that were dramatically increased upon infection. In the susceptible rootstock, a much limited induction was observed that was associated only with catalase isoenzyme 2 (spot 6). Intriguingly, it has been shown that catalase activity in a sugarcane variety resistant to the pathogen Sporisorium scitamineum (Syd.) M. Piepenbr., M. Stoll and Oberw. (smut), was higher than that of a susceptible variety ( $\mathrm{Su}$ et al., 2014). Moreover, this catalase transient over-expression induced the HR response, thereby suggesting that this enzymatic activity may be positively correlated with smut resistance.

On the other hand, levels of $70 \mathrm{kDa}$ heat shock protein (HSP70) (spot 15) were significantly increased only in the resistant rootstock line. HSP70s are a conserved family of molecular chaperones that are involved in protein folding, translocation or degradation. By stabilizing protein conformation, they are essential to maintain cellular homeostasis, especially under stress conditions (Wang et al., 2004). Accordingly, their increase in response to a wide range of stresses has been reported in various species (Kosova et al., 2011).

Our analysis also revealed four spots (spots 1, 2, 16 and 17) induced as result of FORL infection, which were identified as multicystatin isozymes (also known as multiple cysteine protease inhibitor isozymes) with a similar mass (70 kDa) but a different $\mathrm{p} I$ value. They exhibited a different pattern of induction; in fact, whereas the basic spots were induced approximately to the same extent both in sensitive and tolerant lines, the more acidic ones were increased only in the resistant rootstock. Cystatins regulate proteolysis by inhibiting cysteine proteases in various biological processes; they have also been associated with plant defense mechanisms against herbivorous insects, nematodes (Arai et al., 2002) and pathogenic fungi (Soares-Costa et al., 2002). Multicystatins are polymeric cystatins composed by repeating units that can be released by proteolytic cleavage; each unit is able to act as independent inhibitor (Green et al., 2013). Their occurrence in different species (including tomato) has been already reported (Girard et al., 2007). The pattern of isoforms representation observed in this study suggests the existence of a mechanism selectively regulating multicystatin PTMs during pathogen challenge.

In addition to components of the basal defence machinery, proteomic analysis revealed the accumulation of proteins involved in carbohydrate metabolism.

Proteomic data about the impact of pathogenic fungi on plant metabolism are scarce, thereby making interpretation of new results somehow difficult. In our experiments, some enzymes involved in carbohydrate metabolism were identified as differentially represented, namely cytosolic triosephosphate isomerase (TPI; EC 5.3.1.1) (spots 11, 14 and 24), phosphoglycerate mutase (spot 18; EC 5.4.2.1), enolase (spot 19; EC 4.2.1.11) and fruktokinase-2 (spot 7; EC 2.7.1.4). TPI quantitative variations in FORL-infected rootstocks were different for the various protein isoforms we observed; while the more acidic form (spot 11) was down-represented in the sensitive line, the remaining ones resulted moderately (spot 14) or highly (spot 24) over-represented in the susceptible and tolerant cultivar, respectively. TPI catalyzes the reversible isomerization of glyceraldehyde-3-phosphate and dihydroxyacetone phosphate (DHAP); in plants, it occurs as distinct isoforms in the cytosol and the chloroplast. The cytosolic isozyme acts primarily in glycolysis and gluconeogenesis, whereas the plastid TPI functions primarily in carbon assimilation through the Calvin cycle. Interestingly, it has been reported that TPI is induced in rice by methylglyoxal (MG), a cytotoxic compound that accumulates as a glycolysis byproduct or under oxidative stress conditions (Sharma et al., 2012). Authors proposed that TPI induction may serve to alleviate stress by decreasing DHAP concentration, which in turn leads to a reduction of the MG amount within the cell. In yeast, it has been shown that increased levels of MG induced not only TPI but also other glycolytic enzymes, such as phosphoglucose isomerase and phosphofructokinase (Inose and Murata, 1995). In this respect, it is worth noting that phosphoglycerate mutase and enolase, which catalyze the last two steps of the 
glycolytic pathway leading to phosphoenolpyruvate from 2-phosphoglycerate, resulted significantly over-represented only in the resistant interaction. The fruktokinase- 2 spot was contaminated by annexin, so the interpretation of its quantitative trend was ambiguous.

Components of the protein turnover machinery were also identified as differentially represented, namely proteasome subunit $\alpha$ type- 3 and 6 (spots 12 and 13; EC 3.4.25.1), and leucine aminopeptidase 2 (LAP-2) (spot 20; EC 3.4.11.1). Proteasome subunit $\alpha$ type- 3 and 6 are components of the $20 \mathrm{~S}$ plant proteasome complex, which is involved in many cellular processes (Baharami and Gray, 1999), both developmental and adaptative, including defense responses (Becker et al., 2000). Interestingly, it has been shown that the fungal elicitor cryptogein triggers $\alpha-3$ and 6 proteasome subunit expression in tobacco (Dahan et al., 2001), thus suggesting that specific proteolytic events may be involved in the expression of the plant response to the pathogen. In our conditions, levels of $\alpha 3$ and 6 proteasome subunits were increased only in the susceptible interaction. On the other hand, LAP-2 is a member of the ubiquitous M17 family of hexameric peptidases, which remove Leu residues from the N-terminus of protein and peptides (Walling and $\mathrm{Gu}$, 1996). LAP family has been extensively studied in tomato, where two LAPs having neutral or acid $\mathrm{pI}$ values have been identified (Chao et al., 2000). In tomato, two isoforms of acid LAPs are expressed, namely LAP- 1 and LAP-2, which have been shown to be induced by diverse stress, including wounding and pathogens (Matsui et al., 2006), thereby suggesting the involvement of these proteins in the expression of resistance.

Finally, few proteins that did not group in the above categories were identified as strongly over-represented only in the susceptible line, namely ATP synthase $\beta$ subunit (spot 5; EC 3.6.3.14), putative uncharacterized protein Sb01g000380 (spot 3) and predicted protein B9HQY8 (spots 9 and 10). For the latter species, no assignment to a specific function has been obtained.

\section{Conclusion}

The present study demonstrates that scion-rootstock combinations significantly influence tomato sensitivity to FORL, and that grafting can be used as effective control measure in managing FCRR of tomato. Accordingly, results from proteomic analysis highlighted the accumulation of specific proteins which seem to highly contribute in eliciting resistance to FORL. Therefore, on the overall, obtained results significantly contributed to deepen information about the mechanisms of tolerance to FORL, one of the most challenging tomato pathogens, thereby favoring further molecular studies to unravel molecular markers to be used in assisted breeding practices, for the development of tomato varieties with improved resistance to FORL.

\section{Acknowledgments}

This work was partially supported by funds from the Italian MEF - Innovazione e sviluppo del Mezzogiorno - Conoscenze Integrate per Sostenibilità ed Innovazione del Made in Italy AgroalimentareLegge n. 191/2009 and from the P.O.N. Ricerca e Competitività (2007-2013) - The GenoPOMpro project - to AS. This work was also supported by grants from Italian PRIN project 2007 (Vegetable grafting: biophysiological basis, effect on crop and product quality; prot $\mathrm{n}^{\circ}: 2007$ Y2WAE9).

\section{Appendix A. Supplementary data}

Supplementary data related to this article can be found at http:/ dx.doi.org/10.1016/j.plaphy.2014.08.006.

\section{Contributions}

AV, GP, CL and MM designed research; VG, CC, MR, TL and SA performed the experiments; AV, FG, AS, SA and MR analyzed the data; MM, AV, FG and AS wrote the manuscript: All authors read and approved the final manuscript.

\section{References}

Aiello, D., Scuderi, G., Vitale, A., Firrao, G., Polizzi, G., Cirvilleri, G., 2013. A pith necrosis caused by Xanthomonas perforans on tomato plants. Eur. J. Plant Pathol. 137, 29-41.

Afroz, A., Khan, M.R., Ashan, N., Komatsu, S., 2009. Comparative proteomic analysis of bacterial wilt susceptible and resistant tomato cultivars. Peptides 30 , 1600-1607.

Arai, S., Matsumoto, I., Emori, Y., Abe, K., 2002. Plant seed cystatins and their target enzymes of endogenous and exogenous origin.J. Agric. Food Chem. 50, 6612-6617.

Baharami, A.R., Gray, J.E., 1999. Expression of a proteasome a-type gene during tobacco development and senescence. Plant Mol. Biol. 39, 325-333.

Becker, J., Kempf, R., Jeblick, W., Kauss, K., 2000. Induction of competence for elicitation of defence responses in cucumber hypocotyls requires proteasome activity. Plant J. 21, 311-316.

Bletsos, F., Thanassoulopoulos, C., Roupakias, D., 2003. Effect of grafting on growth, yield, and verticillium wilt of eggplant. HortSci. 38, 183-186.

Boller, T., Felix, G.A., 2009. Renaissance of elicitors: perception of microbeassociated molecular patterns and danger signals by pattern-recognition receptors. Annu. Rev. Plant Biol. 60, 379-406.

Casado-Vela, J., Selles, S., Martinez, R.B., 2006. Proteomic analysis of tobacco mosaic virus-infected tomato (Lycopersicon esculentum) fruits and detection of viral coat proteins. Proteomics 6 (Suppl. 1), S196-S206.

Cassaniti, C., Giuffrida, F., Scuderi, D., Leonardi, C., 2011. The effect of rootstock and nutrient solution concentration on eggplant grown in a soilless system. J. Food Agr. Environ. 9, 252-256.

Chao, W.S., Pautot, V., Holzer, F.M., Walling, L.L., 2000. Leucine aminopeptidases: the ubiquity of LAP-N and the specificity of LAP-A. Planta 210, 563-573.

Dahal, D., Heintz, D., van Dorssealer, A., Braun, J.P., Wydra, K., 2009. Pathogenesis and stress related, as well as metabolic proteins are regulated in tomato stems infected with Ralstonia solanacearum. Plant Physiol. Biochem. 47, 838-846.

Du, Y.Y., Wang, P.C., Song, C.P., 2008. Comprehensive functional analysis of the catalase gene family in Arabidopsis thaliana. J. Integr. Plant Biol. 50, 1318-1326.

Dahal, D., Pich, A., Braun, H.P., Widra, K., 2010. Analysis of cell wall proteins regulated in stem of susceptible and resistant tomato species after inoculation with Ralstonia solanacearun, a proteomic approach. Plant Mol. Biol. 73, 643-658.

Dahan, J., Etienne, P., Petitot, A.-S., Houot, V., Blein, J.-P., Suty, L., 2001. Cryptogein affects expression of $\alpha 3, \alpha 6$ and $\beta 120$ S proteasome subunits encoding genes in tobacco. J. Exp. Bot. 52, 194-195.

Dimartino, M., Panebianco, S., Vitale, A., Castello, I., Leonardi, C., Cirvilleri, G., Polizzi, G., 2011. Occurrence and pathogenicity of Pseudomonas fluorescens and P. putida on tomato plants in Italy. J. Plant Pathol. 93, 79-87.

Ercolano, M.R., Sanseverino, W., Carli, P., Ferriello, F., Frusciante, L., 2012. Genetic and genomic approaches for R-gene mediated disease resistance in tomato: retrospects and prospects. Plant Cell. Rep. 31, 973-985.

Gilardi, G., Gullino, M.L., Garibaldi, A., 2011. Reaction of tomato rootstocks to selected soil-borne pathogens under artificial inoculation conditions. Acta Hort. $914,345-348$

Giovannoni, J., 2004. Genetic regulation of fruit development and ripening. Plant Cell. 16, S170-S190

Girard, C.X., Rivard, D., Kiggundu, A., Gleddie, S.C., Cloutier, C., Micahaud, D., 2007. A multicomponent, elicitor-inducible cystatin complex in tomato, Solanum lycopersicum. New Phytol. 173, 841-851.

Giuffrida, F., Cassaniti, C., Leonardi, C., 2013. The influence of rootstock on growth and ion concentrations in pepper (Capsicum annum L.) under saline conditions. J. Hort. Sci. Biotech. 88, 110-116.

Grant, M., Mansfield, J., 1999. Early events in host-pathogen interactions. Curr. Opin. Plant Biol. 2, 312-319.

Green, A.R., Nissen, M.S., Kumar, G.N., Knowles, N.R., Kang C., 2013. Characterization of Solanum tuberosum multicystatin and the significance of core domains. Plant Cell. 25, 5043-5052.

Houtermann, P.M., Speijer, D., Dekker, H.L., De Koster, C.G., Cornelissen, B.J., Rep, M., 2007. The mixed xylem sap proteome of Fusarium oxysporum-infected tomato plants. Mol. Plant. Pathol. 8, 215-221.

Inose, T., Murata, K., 1995. Enhanced accumulation of toxic compound in yeast cells having high glycolytic activity: a case study on the safety of genetically engineered yeast. Int. J. Food Sci. Technol. 30, 141-1456.

Jones, J.B., Jones, J.P., Stall, R.E., Zitter, T.A., 1991. Compendium of Tomato Diseases. American Phytopathological Society, St. Paul, MN, U.S.A.

Kosova, K., Vitamvas, P., Prasil, I.T., Renautt, J., 2011. Plant proteome changes under abiotic stress-contribution of proteomic studies to understanding plant stress response. J. Proteomics 74, 1301-1322.

Lee, J.M., 1994. Cultivation of grafted vegetables. I. Current status, grafting methods, and benefits. HortSci. 29, 235-239.

Leonardi, C., Giuffrida, F., 2006. Variation of plant growth in grafted tomatoes and eggplants. Eur. J. Hort. Sci. 71, 97-101. 
Li, L., Steffens, J.C., 2002. Over-expression of polyphenol oxidase in transgenic tomato plants results in enhanced bacterial disease resistance. Planta 215, 239-247.

Martínez-Ballesta, M.C., Alcaraz-López, C., Muries, B., Mota-Cadenas, C., Carvajal, M. 2010. Physiological aspects of rootstock-scion interactions. Sci. Hort.127, 112-118.

Martínez-Rodríguez, M.M., Santa-Cruz, A., Estañ, M.T., Caro, M., Bolarín, M.C., 2002 Influence of rootstock in the tomato response to salinity. Acta Hort. 573, 455-460.

Matsui, M., Fowler, J.H., Walling, L.L., 2006. Leucine aminopeptidases: diversity in structure and function. Biol. Chem. 387, 1535-1544.

Mayer, A.M., 2006. Polyphenol oxidases in plant and fungi: going places? A review. Phytochemistry 67, 2318-2331.

Mazzeo, M.F., Cacace, G., Ferriello, F., Puopolo, G., Zoina, A., Ercolano, M.R., Siciliano, R.A., 2014. Proteomic investigation of response to FORL infection of tomato roots. Plant Physiol. Biochem. 74, 42-49.

Metha, A., Brasilero, A.C.M., Souza, D.S.L., Romano, E., Campos, M.A., Grossi-de-Sà, M.F., Silva, M.S., Franco, O.L., Fragoso, R.R., Bevitori, R., Rocha, T.L., 2008. Plant-pathogen interactions: what is proteomics telling us? FEBS J. 27, 3731-3746.

Phypiapong, P., Hunt, M.D., Steffens, J.C., 2004. antisense downregulation of poliphenol oxidase results in enhanced disease susceptibility. Planta 220, 105-107.

Ramagli, L.S., Rodriguez, L.V., 1985. Quantitation of microgram amounts of proteins in two-dimensional polyacrilamide gel electrophoresis sample buffer. Electrophoresis 6, 559-563.

Rivero, R.M., Ruiz, J.M., Romero, L., 2003. Role of grafting in horticultural plants under stress conditions. J. Food Agr. Environ. 1, 70-74.

Rocco, M., D'Ambrosio, C., Arena, S., Faurobert, M., Scaloni, A., Marra, M., 2006. Proteomic analysis of tomato fruits from two ecotypes during ripening. Proteomics 6, 3781-3791.

Savidor, A., Teper, D., Gartemann, K.H., Eichenlaub, R., Chalupowicz, L., ManulisSasson, S., Barash, I., Tews, H., Mayer, K., Giannone, R.J., Hettich, R.L., Sessa, G., 2012. The Clavibacter michiganensis subsp. michiganensis-tomato interactome reveals perception of pathogen by the host and suggests mechanisms of infection. J. Proteome Res. 11, 736-750.

Savvas, D., Savva, A., Ntatsi, G., Ropokis, A., Karapanos, I., Krumbein, A., Olympios, C., 2011. Effects of three commercial rootstocks on mineral nutrition, fruit yield, and quality of salinized tomato. J. Plant Nutr. Soil Sci. 174, 154-162.
Scippa, G.S., Rocco, M., Ialicicco, M., Trupiano, D., Viscosi, V., Di Michele, M. Arena, S., Chiatante, D., Scaloni, A., 2010. The proteome of lentil (Lens culinaris Medik.) seeds: discriminating between landraces. Electrophoresis 31, 497-506.

Sharma, S., Mustafiz, A., Singla-Pareek, S.L., Srivastava, P.S., Sopory, S.K., 2012. Characterization of stress and methyglyoxal inducible triose phosphate isomerase (Osc) from rice. Plant Signal. Behav. 7, 1337-1345.

Soares-Costa, A., Beltramini, L.M., Thiemann, O.H., Henrique-Silva, F., 2002 A sugarcane cystatin: recombinant expression, purification, and antifungal activity. Biochem. Biophys. Res. Commun. 6, 1194-1199.

Su, Y., Guo, J., Ling, H., Chen, S., Wang, S., Xu, L., Allanz, A.C., 2014. Isolation of a novel peroxisomal catalase gene from sugarcane, which is responsive to biotic and abiotic stresses. PLOS One 9 (1), e84426.

Talamo, F., D'Ambrosio, C., Arena, S., Del Vecchio, P., Ledda, L., Zehender, G., et al. 2003. Proteins from bovine tissues and biological fluids: defining a reference electrophoresis map for liver, kidney, muscle, plasma and red blood cells. Proteomics 3, 440-460.

Thomma, B.P.H.J., van Esse, H.P., Crous, P.W., de Wit, P.J.G.M., 2005. Cladosporium fulvum (syn. Passalora fulva), a highly specialized plant pathogen as a model for functional studies on plant pathogenic Mycosphaerellaceae. Mol. Plant Pathol. 6, 379-393.

van Loon, L.C., Rep, M., Pieterse, C.M.J., 2006. Significance of inducible defenserelated proteins in infected plants. Annu. Rev. Phytopathol. 44, 135-162.

Vitale, A., Castello, I., Cascone, G., D'Emilio, A., Mazzarella, R., Polizzi, G., 2011. Reduction of corky root infections on greenhouse tomato crops by soil solarization in south Italy. Plant Dis. 95, 195-201.

Vitale, A., Castello, I., D'Emilio, A., Mazzarella, R., Perrone, G., Epifani, F., Polizzi, G., 2013. Short-term effects of soil solarization in suppressing Calonectria microsclerotia. Plant Soil. 368, 603-617.

Wang, W., Vinocur, B., Shoseyov, O., Altman, A., 2004. Role of the plant heat-shock proteins and molecular chaperones in the abiotic stress response. Trends Plant Sci. 9, 244-252.

Walling, L.L., Gu, Y.-Q., 1996. Plant aminopeptidases: occurrence, function and characterization. In: The Aminopeptidases. R.G. Landes Co, pp. 174-219. 